\title{
Interaction between lung cancer cells and astrocytes via specific inflammatory cytokines in the microenvironment of brain metastasis
}

\author{
Toshihiro Seike $\cdot$ Kyota Fujita $\cdot$ Yukiko Yamakawa \\ Mizuho A. Kido · Soichi Takiguchi · Norihiro Teramoto • \\ Haruo Iguchi · Mami Noda
}

Received: 13 July 2009/ Accepted: 25 September 2010/Published online: 17 October 2010

(C) The Author(s) 2010. This article is published with open access at Springerlink.com

\begin{abstract}
The incidence of brain metastasis is increasing, however, little is known about molecular mechanism responsible for lung cancer-derived brain metastasis and their development in the brain. In the present study, brain pathology was examined in an experimental model system of brain metastasis as well as in human brain with lung cancer metastasis. In an experimental model, after 3-6 weeks of intracardiac inoculation of human lung
\end{abstract}

The study was approved by the Animal Care and Use Committee at Kyushu University and carried out in accordance with the National Institutes of Health Guide for the Care and Use of Laboratory Animals.

Electronic supplementary material The online version of this article (doi:10.1007/s10585-010-9354-8) contains supplementary material, which is available to authorized users.

T. Seike $\cdot$ K. Fujita $\cdot$ Y. Yamakawa $\cdot$ M. Noda $(\bowtie)$

Laboratory of Pathophysiology, Graduate School

of Pharmaceutical Sciences, Kyushu University,

3-1-1 Maidashi, Higashi-ku, Fukuoka 812-8582, Japan

e-mail: noda@phar.kyushu-u.ac.jp

M. A. Kido

Department of Oral Anatomy and Cell Biology,

Graduate School of Dental Sciences, Kyushu University,

Fukuoka 812-8582, Japan

S. Takiguchi

Institute for Clinical Research, National Kyushu Cancer Center,

Fukuoka 811-1395, Japan

\section{N. Teramoto}

Division of Pathology, National Hospital Organization Shikoku Cancer Center, Matsuyama, Ehime 791-0280, Japan

H. Iguchi

Clinical Research Institute, National Hospital Organization

Shikoku Cancer Center, Matsuyama, Ehime 791-0280, Japan cancer-derived (HARA-B) cells in nude mice, wide range of brain metastases were observed. The brain sections showed significant increase in glial fibrillary acidic protein (GFAP)-positive astrocytes around metastatic lesions. To elucidate the role of astrocytes in lung cancer proliferation, the interaction between primary cultured mouse astrocytes and HARA-B cells was analyzed in vitro. Co-cultures and insert-cultures demonstrated that astrocytes were activated by tumor cell-oriented factors; macrophage migration inhibitory factor (MIF), interleukin-8 (IL-8) and plasminogen activator inhibitor-1 (PAI-1). Activated astrocytes produced interleukin-6 (IL-6), tumor necrosis factor- $\alpha$ (TNF- $\alpha$ ) and interleukin-1 $\beta$ (IL-1 $\beta$ ), which in turn promoted tumor cell proliferation. Semi-quantitative immunocytochemistry showed that increased expression of receptors for IL-6 and its subunits gp130 on HARA-B cells. Receptors for TNF- $\alpha$ and IL- $1 \beta$ were also detected on HARA-B cells but down-regulated after co-culture with astrocytes. Insert-culture with astrocytes also stimulated the proliferation of other lung cancer-derived cell lines (PC-9, QG56, and EBC-1). These results suggest that tumor cells and astrocytes stimulate each other and these mutual relationships may be important to understand how lung cancer cells metastasize and develop in the brain.

Keywords Interleukin-8 - Macrophage migration inhibitory factor - Plasminogen activator inhibitor-1 . Interleukin- $6 \cdot$ Tumor necrosis factor- $\alpha \cdot$ Interleukin- $1 \beta$

$\begin{array}{ll}\text { Abbreviations } \\ \text { ab } & \text { Antibody } \\ \text { ACM } & \text { Astrocyte conditioned medium } \\ \text { BSA } & \text { Bovine serum albumin } \\ \text { Cdna } & \text { Complementary DNA }\end{array}$




\begin{tabular}{|c|c|}
\hline DAPI & $\begin{array}{l}4^{\prime}, 6^{\prime} \text {-diamidino-2-phenylindole } \\
\text { hydrochloride }\end{array}$ \\
\hline DMEM & Dulbecco's modified Eagle medium \\
\hline EDTA & Ethylenediaminetetraacetic acid \\
\hline EGFR & Epidermal growth factor receptor \\
\hline FCS & Fetal calf serum \\
\hline FITC & Fluoresceinisothiocyanate \\
\hline GFAP & Glial fibrillary acidic protein \\
\hline MT1-MMP & Membrane type-1 matrix metalloproteina \\
\hline $\mathrm{HCM}$ & HARA-B conditioned medium \\
\hline $\mathrm{H}-\mathrm{ACM}$ & HARA-B-astrocytes conditioned medium \\
\hline ICM & Insert culture medium \\
\hline IGF-1 & Insulin-like growth factor-1 \\
\hline IL-1 $\beta$ & Interleukin- $1 \beta$ \\
\hline IL-1ra & Interleukin-1 receptor antagonist \\
\hline IL-3 & Interleukin-3 \\
\hline IL-6 & Interleukin-6 \\
\hline MIF & Macrophage migration inhibitory factor \\
\hline PAI-1 & Plasminogen activator inhibitor \\
\hline PBS & Phosphate buffer saline \\
\hline PDGF & Platelet-derived growth factor \\
\hline PFA & Paraformaldehyde \\
\hline PTHrP & Parathyroid hormone-related protein \\
\hline SERPINE1 & $\begin{array}{l}\text { Serpin peptidase inhibitor plasminogen } \\
\text { activator inhibitor type } 1 \text { ) }\end{array}$ \\
\hline $1 \in F-p$ & Transforming growth factor- $\beta$ \\
\hline 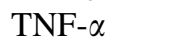 & Tumor necrosis factor- $\alpha$ \\
\hline
\end{tabular}

\section{Introduction}

Metastasis is the principal cause of the morbidity and death of cancer patients. The incidence of brain metastasis has been increasing in recent years, especially in breast cancer and lung cancer [1]. In the process of metastasis formation, the interaction between the metastatic tumor cells and host cells plays an important role in the microenvironment of the metastatic sites [2]. However, a molecular mechanism for brain metastasis is poorly understood to date. In the central nervous system, activated glial cells contribute to the innate immune response and produce a large variety of different inflammatory mediators as a chronic inflammatory reaction [3]. A similar mechanism could function in cell survival, growth, proliferation and colonization, invasion and motility of metastatic tumor cells in the microenvironment of brain metastases $[4,5]$. Among the glial cells, astrocytes are the most abundant cell population and play an important role in maintaining homeostasis of the brain [6]. Astrocytes have been shown to produce a wide variety of cytokines including interleukin-1 (IL-1), interleukin-3 (IL-3), interleukin-6 (IL-6), tumor necrosis factor- $\alpha$ (TNF- $\alpha$ ), transforming growth factor- $\beta$ (TGF- $\beta$ ), insulin-like growth factor-1 (IGF-1) and platelet-derived growth factor (PDGF) [7-10]. Among them, it was suggested that IL- 6 , TGF- $\beta$ and IGF- 1 may contribute to the development of brain metastasis by breast cancer cells [11]. As for brain metastasis by lung cancer cells, it is not known whether or not the same cytokines are involved and what the difference between brain metastases derived by breast cancer cells and lung cancer cells.

Therefore, in the present study, we examined brain pathology in an experimental model system of brain metastasis, using HARA-B cells derived from human lung cancer cells, and assessed the effects of astrocytes on the growth of HARA-B cells as well as three other non-small cell lung cancer cell lines (PC-9, QG56, and EBC-1) in vitro. Furthermore, astrocytes-derived factors conducive to tumor cell growth and their receptor expression on tumor cells were investigated.

\section{Materials and methods}

\section{Experimental model for brain metastasis}

The study was approved by the Animal Care and Use Committee at Kyushu University and carried out in accordance with the National Institutes of Health Guide for the Care and Use of Laboratory Animals. Male 5-week-old nude mice (BALB/c nu/nu) (Kyudo, Kumamoto, Japan), kept in a specific pathogen-free environment, were used. A single suspension of human lung squamous cell carcinomaderived cells (HARA-B) $\left(2 \times 10^{5}\right.$ cells $/ 0.2 \mathrm{ml}$ PBS) was inoculated into the left ventricle of the heart in nude mice according to the method described previously [12]. After 4-6 weeks, brains were subjected for immunohistochemical staining.

\section{Human tissue samples}

A total of 6 paraffin-embedded samples from patients with lung tumor brain metastasis were used. All sections were obtained from the National Hospital Organization Shikoku Cancer Center. Use of the human specimens was in accordance with the University Ethics Commission. The formalin-fixed, paraffin-embedded archival tissue blocks were retrieved, and matching hematoxylin and eosin ( $\mathrm{H} \& \mathrm{E})$ stained slides were reviewed and screened for representative tumor regions by a neuropathologist.

Immunohistochemistry

Nude mice were perfused transcardially with $50 \mathrm{ml}$ of 10 $\mathrm{U} / \mathrm{ml}$ heparin and $0.5 \%$ procaine in PBS and $4 \%$ paraformaldehyde (PFA) in PBS prior to excision of the brain. 
Then the brain was removed, post-fixed for $3 \mathrm{~h}$, and cryoprotected for $24 \mathrm{~h}$ in PBS containing 20\% sucrose. The brain was cut into slices ( $30 \mu \mathrm{m}$ thick) using a cryostat and the sections were placed on glass slides. In order to acquire the better immunoreactive images, sections were autoclaved with $0.01 \mathrm{M}$ citrate buffer solution ( $\mathrm{pH} 6.0$ ), permeabilized with $0.3 \%$ TritonX-100 in PBS for 15 min, and then blocked in BlockAce (Dainippon Pharmaceutical, Japan) for $1 \mathrm{~h}$ at room temperature. Sections were incubated with mouse anti-human cytokeratin monoclonal antibody (AE1/AE3 pool of cytokeratin) (Dako, Glostrup, Denmark, $1: 100)$ at $4^{\circ} \mathrm{C}$ overnight. Biotinylated anti-mouse $\operatorname{IgG}$ (Jackson, 1:200) were incubated for $2 \mathrm{~h}$ at room temperature, followed by the incubation with streptavidin Alexa488 (Molecular Probes, 1:500) for $2 \mathrm{~h}$ at room temperature. For double-staining of cytokeratin and GFAP, sections were incubated with $\mathrm{Cy} 3$-conjugated anti-GFAP antibody (Sigma, USA) (1:1000) at $4^{\circ} \mathrm{C}$ overnight after staining of cytokeratin. Every treatment was followed by washing three times with PBS containing 0.3\% TritonX-100 for $5 \mathrm{~min}$. The sections were mounted in the Perma Fluor Aqueous Mounting Medium (Thermo Shandon, Pittsburgh, PA, USA) and analyzed with a confocal microscope (LSM510 META, Carl Zeiss, Co. Ltd. Germany). Z-stack images were obtained from each section by LSM 510 META and total intensity were calculated by LSM image browser.

As for human tissue samples, after removal of paraffin in xylene and rehydration in a graded of alcohols $(100 \%$, $90 \%, 80 \%, 70 \%, 60 \%$ ), sections were incubated for $30 \mathrm{~min}$ in $0.05 \mathrm{M}$ phosphate buffer $\mathrm{pH} 7.6$ containing tripsin and $\mathrm{KCl}$ for antigen retrieval. Then, the sections were incubated for $1 \mathrm{~h}$ in $0.3 \% \mathrm{H}_{2} \mathrm{O}_{2}$, and blocked in PBS containing $1 \%$ BSA and 5\% normal donkey serum (Jackson Immuno Research Laboratories Inc., West Grove, PA, USA) for $1 \mathrm{~h}$ at room temperature. Then, the sections were incubated with anti-GFAP antibody (ImmunoStar) $(1: 15)$ at $4^{\circ} \mathrm{C}$ overnight, goat anti-rabbit IgG Alexa 568 (Molecular Probes) (1:500) for $3 \mathrm{~h}$ at room temperature and FITCconjugated anti-human cytokeratin antibody (CAM5.2) (Becton-Dickinson Biosciences, New Jersey, USA) (undiluted solution) for $1 \mathrm{~h}$ at room temperature. Every treatment was followed by washing three times with PBS containing $0.3 \%$ TritonX-100 for $5 \mathrm{~min}$. The sections were mounted in the Perma Fluor Aqueous Mounting Medium (Thermo Shandon, Pittsburgh, PA, USA) and analyzed with a confocal microscope (LSM510 META, Carl Zeiss, Co. Ltd. Germany).

\section{Cell culture}

Primary glial cell cultures were performed according to the method described previously [13]. Briefly, the cerebral cortex obtained from 1-day-old C57BL/6 mice (Kyudo,
Kumamoto, Japan) were isolated under a dissecting microscope and carefully separated from the choroid plexus and meninges. The isolated cerebral cortex were minced and treated with trypsin-EDTA solution $(0.25 \%$ trypsin, $1 \mathrm{mM}$ EDTA) and 1500 U DNase in Dulbecco's modified Egle medium (DMEM; Nissui, Tokyo, Japan) at $37^{\circ} \mathrm{C}$ for $10 \mathrm{~min}$. Cell suspensions were filtered through $70 \mu \mathrm{m}$ pore size mesh (BD Falcon, Bedford, MA, USA) into DMEM containing $10 \%$ fetal calf serum (FCS; Hyclone, UT, USA), $2 \mathrm{mM}$ L-glutamine, $100 \mathrm{U} / \mathrm{ml}$ penicillin, $100 \mu \mathrm{g} / \mathrm{ml}$ streptomycin, $0.37 \% \mathrm{NaHCO}_{3}$, and $110 \mu \mathrm{g} / \mathrm{ml}$ pyruvic acid. After centrifugation, cells were filtered through $40 \mu \mathrm{m}$ pore size-mesh (BD Falcon), plated into poly-L-lysine coated $75 \mathrm{~cm}^{2}$ cell culture flask at the density of two brains per flask in $10 \mathrm{ml}$ of DMEM, and maintained at $37^{\circ} \mathrm{C}$ in $10 \%$ $\mathrm{CO}_{2}-90 \%$ air with a change of the medium twice per week. Astrocytes were obtained after 28 days of mixed glial cell cultures as follows. After removing other glial cells by shaking the flasks, the astroglial layer was removed from the flasks by the treatment with trypsin-EDTA solution (0.06\% trypsin, $0.25 \mathrm{mM}$ EDTA in serum free DMEM) at $37^{\circ} \mathrm{C}$ for $45 \mathrm{~min}$. Suspended astrocytes were filtered through $40 \mu \mathrm{m}$ pore size-mesh and seeded. Astrocyte purity ranged from 90 to $95 \%$ as determined by immunostaining with anti-GFAP antibody (Sigma, St. Louis, MO, USA) (data not shown). Astrocytes were maintained in the same medium used for cell suspension from cerebral cortex at $37^{\circ} \mathrm{C}$ in $10 \% \mathrm{CO}_{2}-90 \%$ air. HARA-B cells and other lung cancer cell lines (QG56, EBC-1; squamous cell carcinoma) and PC-9 (non-small cell lung cancer cell) were maintained under the same condition. Cells were grown in $25 \mathrm{~cm}^{2}$ cell culture flask (Nalge Nunc International), and single-cell suspension of cells were obtained by trypsin treatment.

\section{Cell proliferation assay}

In the co-culture experiment, HARA-B cells $\left(0.5 \times 10^{3}\right.$ cells/well $)$ and astrocytes $\left(2.5 \times 10^{3}\right.$ or $5 \times 10^{3}$ cells/well $)$ were seeded into 8-well cell culture slide (BD Falcon) in DMEM for $24 \mathrm{~h}$. Then, cells were rinsed twice with PBS and incubated in serum free DMEM. After $72 \mathrm{~h}$ of co-culture, cells were fixed with $4 \%$ PFA for $30 \mathrm{~min}$ at room temperature and permeabilized with $0.3 \%$ TritonX100 in PBS for $15 \mathrm{~min}$, followed with blocking solution containing 1\% BSA and 5\% normal donkey serum (Jackson) in PBS for $1 \mathrm{~h}$ at room temperature. Then cells were incubated with mouse anti-human cytokeratin monoclonal antibody (AE1/AE3 pool of cytokeratin) (Dako, Glostrup, Denmark) $(1: 100)$ at $4{ }^{\circ} \mathrm{C}$ overnight, followed by the incubation with the secondary antibody (FITC-conjugated anti-mouse IgG; Sigma, 1:500) for $5 \mathrm{~h}$ at room tempera-

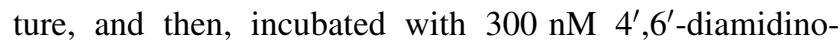
2-phenylindole hydrochloride (DAPI, Sigma) for $30 \mathrm{~min}$ at 
room temperature. The number of HARA-B cells in each well, which were positively stained with an anti-human cytokeratin antibody, was counted using a digital camera system (Axio Cam, Carl Zeiss) mounted on a light and fluorescent microscope (Axopscope2 plus, Carl Zeiss). The results were expressed as the percentage of control (single cell culture of HARA-B cells).

Insert culture-medium was obtained as follows. Astrocytes $\left(5 \times 10^{4}\right.$ cells/well) were plated in 6-well cell culture plates (Falcon). Tumor cells derived from each lung tumor (EBC-1, PC9, QG56 and HARA-B cells) $\left(5 \times 10^{3}\right.$ cells/ insert) were plated in cell culture-inserts (membrane pore size $0.4 \mu \mathrm{m}$; Becton-Dickinson), and then, placed in the well of astrocyte cultures. After $24 \mathrm{~h}$ of the insert-culture, cells were rinsed twice with PBS, incubated in serum-free DMEM for further $48 \mathrm{~h}$. Then, the medium was collected. Each conditioned medium was centrifuged to remove debris $\left(1500 \mathrm{rpm}\right.$ for $10 \mathrm{~min}$ at $\left.4^{\circ} \mathrm{C}\right)$ before use. Tumor cells derived from each lung tumor $\left(0.5 \times 10^{3}\right.$ cells/well $)$ were seeded into 8-well cell culture slide (BD Falcon) in DMEM for $24 \mathrm{~h}$. Then, cells were rinsed twice with PBS and incubated in each Insert culture-medium. After $72 \mathrm{~h}$, cells were fixed with $4 \%$ PFA for $30 \mathrm{~min}$ at room temperature and incubated with $300 \mathrm{nM}$ DAPI for $10 \mathrm{~min}$ at room temperature. The number of tumor cells in each well, which were positively stained with DAPI, was counted as mentioned above. The results were expressed as the percentage of control (each tumor cells cultured in serum-free DMEM for $72 \mathrm{~h}$ ).

The astrocyte-conditioned medium (ACM) was obtained from the primary culture of astrocytes at a density of $10^{4}$ cells/well in serum free DMEM after $72 \mathrm{~h}$-incubation. This ACM was centrifuged $\left(1500 \mathrm{rpm}\right.$ for $10 \mathrm{~min}$ at $\left.4^{\circ} \mathrm{C}\right)$, and then, added to HARA-B cells cultured for 1 day at a volume of $25 \%$ or $50 \%$. The number of HARA-B cells were counted after the $72 \mathrm{~h}$-incubation in the presence of $\mathrm{ACM}$ as described above.

HARA-B-stimulated astrocyte-conditioned medium (H-ACM) was obtained as follows. Culture medium of HARA-B cells $\left(5 \times 10^{3}\right.$ cells/well $)$ were added to astrocytes cultures $\left(5 \times 10^{4}\right.$ cells/well $)$ and incubated for $24 \mathrm{~h}$. Then the medium was collected and centrifuged to remove debris $\left(1500 \mathrm{rpm}\right.$ for $10 \mathrm{~min}$ at $\left.4^{\circ} \mathrm{C}\right)$ before use.

In the proliferation assay using recombinant mouse cytokines, HARA-B cells $24 \mathrm{~h}$ after plating were rinsed twice with PBS and incubated in serum free DMEM with each cytokine (mIL- $1 \beta, 1$ to $10 \mathrm{pg} / \mathrm{ml}$; mTNF- $\alpha, 10$ to $500 \mathrm{pg} / \mathrm{ml} ; \mathrm{mIL}-6,10$ to $500 \mathrm{pg} / \mathrm{ml}$, Peprotech, Rocky Hill, NJ, USA). After 72 h, HARA-B cells were immunostained and counted as mentioned above.

In the experiments using neutralizing antibodies, cells were plated, rinsed twice with PBS after $24 \mathrm{~h}$, and incubated in serum free DMEM with each specific neutralizing antibodies; mIL-1 $\beta$ antibody (ab), 0.2 to $2.0 \mu \mathrm{g} / \mathrm{ml}$ (R\&D systems, Minneapolis, MN USA), mTNF- $\alpha$ ab, 0.2 to $2.0 \mu \mathrm{g} / \mathrm{ml}$ (R\&D systems), mIL-6 ab, 2.0 to $20 \mathrm{ng} / \mathrm{ml}$ (Peprotech) for $48 \mathrm{~h}$. As controls, rat IgG (Sigma) and rabbit IgG (R\&D systems) were used. HARA-B cells were immunostained and counted as mentioned above.

\section{SYBR green-based real-time quantitative RT-PCR}

HARA-B cells $\left(1 \times 10^{5}\right.$ cells/insert $)$ and astrocytes $\left(1 \times 10^{6}\right.$ cells/well $)$ were cultured in cell culture-insert systems as mentioned above. Cells were collected by treatment with trypsin after 24,48 and $72 \mathrm{~h}$ of insert-culture. As controls, single cell culture of HARA-B cells or astrocytes was used. Total RNA was isolated from each cell type by an extraction procedure using the RNA blood mini kit (QIAGEN in Japan). Contaminating DNA was removed by RNase-free DNase (QIAGEN). Single-strand cDNA was synthesized from cellular mRNA by using random 9 mer and RNA PCR kit (AMV) (Takara Bio Inc., Ootsu, Japan). PCR amplification was undertaken for plain SYBR Green I detection in using Light Cycler system (Roche Diagnostics GmbH, Mannheim, Germany). Each reaction was carried out in a total volume of $20 \mu \mathrm{l}$ in glass capillary, containing $1 \mu \mathrm{l}$ of cDNA, 2,3 or $4 \mathrm{mM} \mathrm{MgCl}_{2}$, $10 \%$ LightCycler-DNA Master SYBR Green I buffer (Taq DNA polymerase, reaction buffer, deoxynucleotide triphosphate mix, $10 \mathrm{mM} \mathrm{MgCl}_{2}$ and SYBR Green I dye) and $0.5 \mu \mathrm{M}$ of each primer (Table 1). After the PCR reaction, we confirmed that there was no primer dimer and non specific product in each PCR product by agarose gel electrophoresis and staining with ethidium bromide. The expression of all target genes was normalized to $\beta$-actin. Analysis was carried out with Light Cycler 3.5 software (Roche) and Microsoft Excel.

To see the reconstituted effects of HARA-B-derived substances on astrocytic expression of TNF- $\alpha$, IL- $1 \beta$ and IL-6, the mouse primary astrocyte cells were treated with human IL-8 (R\&D systems, Minneapolis, MN, U.S.A), MIF (R\&D systems), or PAI-1 (Peprotech, Rocky Hill, U.S.A) for $72 \mathrm{~h}$ in serum-free medium. Total RNA was extracted using an RNeasy Plus Mini kit (QIAGEN, Hilden, Germany) and QIA shredder (QIAGEN). cDNA was synthesized using a SuperScript VILO cDNA synthesis kit (Invitrogen) SYBR-Green real-time PCR (Applied Biosystems, Foster City, CA) was performed on cDNA prepared from each sample using Platinum SYBR-Green qPCR Super-Mix-UDG (Invitrogen) and $0.5 \mu \mathrm{M}$ each primer (Table 1). Thermal cycling condition were $10 \mathrm{~min}$ at $95^{\circ} \mathrm{C}, 45$ cycles at $95^{\circ} \mathrm{C}$ for $15 \mathrm{~s}$, followed by $1 \mathrm{~min}$ at $60^{\circ} \mathrm{C}$. Data Analysis was completed using the ABI PRISM 7500HT Sequence detection software (Applied Biosystems). $\beta$-actin was used for normalization. 
Table 1 Gene-specific primer pairs for real-time RT-PCR

\begin{tabular}{|c|c|c|c|}
\hline & \multicolumn{2}{|c|}{ Primer sequence $\left(5^{\prime}-3^{\prime}\right)$} & Length (bp) \\
\hline \multicolumn{4}{|l|}{ Mouse } \\
\hline \multirow[t]{2}{*}{$\beta$-actin } & Sense & ACCAACTGGGACGACATGGAG & 380 \\
\hline & Antisense & GTGGTG GTGAAG CTGTAGCC & \\
\hline \multirow[t]{2}{*}{ IL-6 } & Sense & ACAAGTCGGAGGCTTAATTACACAT & 79 \\
\hline & Antisense & AATCAG AATTG CCATTGCACAA & \\
\hline \multirow[t]{2}{*}{ IL-1 $\beta$} & Sense & CTCCATGAG CTTTGTACAAG G & 240 \\
\hline & Antisense & TG CTG ATGTACCAGTTG GG G & \\
\hline \multirow[t]{2}{*}{ TNF- $\alpha$} & Sense & ATGAGCACAGAAAGCATGATCCGC & 692 \\
\hline & Antisense & CCAAAGTAGACCTG CCCG GACTC & \\
\hline \multirow[t]{2}{*}{ TGF- $\beta 1$} & Sense & GAG AG CCCTGG GATACCAACTACTG & 173 \\
\hline & Antisense & GTGTGTCCAGG CTCCAAATGTAG & \\
\hline \multirow[t]{2}{*}{ EGF } & Sense & TTTTGCCTCAGAAG GAGTGG & 150 \\
\hline & Antisense & GG CCACACTTG G CAGTATATC & \\
\hline \multirow[t]{2}{*}{ IGF-I } & Sense & GGACCAGAGACCCTTTGCGGGG & 209 \\
\hline & Antisense & GG CTG CTTTTGTAGG CTTCAGTG G & \\
\hline \multirow[t]{2}{*}{ PDGF-B } & Sense & TGAAATGCTGAGCGACCAC & 137 \\
\hline & Antisense & AGCTTTCCAACTCGACTCC & \\
\hline \multicolumn{4}{|l|}{ Human } \\
\hline \multirow[t]{2}{*}{$\beta$-actin } & Sense & ATG GCCACG GCTGCTTCCAG C & 237 \\
\hline & Antisense & CATGGTGGTGACAGACCG CCG & \\
\hline \multirow[t]{2}{*}{ IL-6Ra } & Sense & CATTGCCATTGTTCTGAGGTT & 271 \\
\hline & Antisense & AGTAGTCTGTATTG CTGATGT & \\
\hline \multirow[t]{2}{*}{ gpi30 } & Sense & TGGAGTGAAGAAGCAAGTGG & 303 \\
\hline & Antisense & AACAGCTGCATCTGATTTGC & \\
\hline \multirow[t]{2}{*}{ TNFRI } & Sense & TG CCTACCCCAGATTG AG AA & 121 \\
\hline & Antisense & ATTTCCCACAAACAATGGAGTAG & \\
\hline \multirow[t]{2}{*}{ IL-1 Rtl } & Sense & AAG GTG GAG G ATTCAGG ACAT & 284 \\
\hline & Antisense & AG CCTATCTTTGACTCCACTA & \\
\hline \multirow[t]{2}{*}{ IL-1 ra } & Sense & CAGAAGACCTCCTGTCCTATGAGG & 424 \\
\hline & Antisense & GCTGTGCAGAGGAACCA & \\
\hline
\end{tabular}

\section{Cytokine ELISA assay}

Co-cultures of HARA-B cells $\left(0.5 \times 10^{3}\right.$ cells/well $)$ and astrocytes $\left(5 \times 10^{3}\right.$ cells/well $)$ or astrocytes alone $\left(5 \times 10^{3}\right.$ cells/well) were seeded into 8 -well cell culture slides in DMEM with FCS for $24 \mathrm{~h}$. Then, cells were rinsed twice with PBS and incubated in serum free DMEM. After 48 or $72 \mathrm{~h}$ of culture, each conditioned medium was collected and centrifuged to remove debris $\left(1500 \mathrm{rpm}\right.$ for $10 \mathrm{~min}$ at $4^{\circ} \mathrm{C}$ ) before use. The amount of mouse IL- $1 \beta$, TNF- $\alpha$ and IL- 6 in each conditioned medium was measured with an ELISA kit for mouse cytokines (Biosource International). The absorbency at $450 \mathrm{~nm}$ was measured by a Microplate Reader (Immuno-Mini NJ-2300, Nalge Nunc International).

Cytokine proteome array

HARA-B cells $\left(1 \times 10^{6}\right.$ cells $)$ were grown in $10 \mathrm{~cm}$ dish (BD, Franklin Lake, NJ, U.S.A) for $24 \mathrm{~h}$ and culture medium was collected. Protein array analysis was performed according to the manufacture's instruction. Positive controls were located in the upper left-hand corner (two spots), upper right-hand corner (two spots) and the lower left-hand corner (two spots) of each array kit. Medium and culture medium were measured using the human cytokine array Panel A (Proteome Profiler) (R\&D systems, Minneapolis, MN, U.S.A). Horseradish peroxidase substrate (Thermo scientific, Rockford, IL, U.S.A) was used to detect protein expression and captured by exposure to X-ray Film (FUJIFILM, Tokyo, Japan).

Immunocytochemistry

HARA-B cells $\left(0.5 \times 10^{3}\right.$ cells/well $)$ with or without astrocytes $\left(5 \times 10^{3}\right.$ cells/well) were seeded into 8 -well cell culture slides in complete medium. Cells were fixed with 4\% PFA for $30 \mathrm{~min}$ at room temperature and permeabilized with $0.3 \%$ TritonX-100 in PBS for 15 min and blocked 
in PBS containing 1\% BSA and 5\% normal donkey serum (Jackson) for $1 \mathrm{~h}$ at room temperature. Cells were incubated with primary antibodies, containing monoclonal mouse anti-human cytokeratin antibody (AE1/AE3 pool of cytokeratin) (Dako, 1:100), rabbit anti-human IL-6R $\alpha$ antibody (Santa Cruz, CA, USA) (1:200), rabbit antihuman gp130 antibody (Santa Cruz, 1:500), rabbit antihuman IL-1RtI antibody (Santa Cruz, 1:200), and goat anti-human TNFRI (Santa Cruz, 1:100) overnight at $4^{\circ} \mathrm{C}$. Control cells were incubated without primary antibody (PBS containing 1\% BSA) to test non-specific staining. The cells were then incubated for $5 \mathrm{~h}$ at room temperature with secondary antibody, containing FITC-conjugated antimouse IgG (Sigma, 1:500), Cy3-conjugated anti-rabbit IgG (Jackson, 1:500) and Cy3-conjugated anti-goat IgG (Jackson, 1:500) and then for $30 \mathrm{~min}$ at room temperature with $300 \mathrm{nM} 4^{\prime}, 6^{\prime}$-diamidino-2-phenylindole hydrochloride (DAPI, Sigma). Slides were mounted in the Perma Fluor Aqueous Mounting Medium (Thermo) and were analyzed with a Zeiss LSM510 META confocal microscope.

\section{Statistical analysis}

One-way analysis of variance (ANOVA) and post-hoc Bonferroni/Dunn test were used to examine the statistical differences. Differences were considered significant at $P<0.05$.

\section{Results}

Histological analyses of lung cancer cell-induced brain metastasis

Though one of the lung cancer cell line (HARA-B) induces bone metastasis [12], it was not known that HARA-B cells also induce brain metastasis. At 3 weeks after the inoculation of HARA-B cells into cardiac ventricle, metastatic foci were mainly found in midbrain-lateral cortex (data not shown). At 4-6 weeks, metastatic foci of various sizes were found throughout the brain. Bigger metastatic foci attracted more astrocytes (Fig. 1a), with the correlation factor of tumor size and GFAP intensity of 0.638 (Fig. 1b). Though the incidence of brain metastasis was different depending on each mouse, the highest incidence was generally observed in cerebral cortex and hippocampus (Fig. 1c). The correlation factor of tumor size and GFAP intensity was higher in hippocampus (0.716) than that in cortex (0.4927) (Fig. 1d). On the other hand, brain's immune cells, including microglia and/or invaded macrophages, also showed accumulation around tumor cells but did not show stronger correlation between tumor size and immune cell population (data not shown). These results suggest that

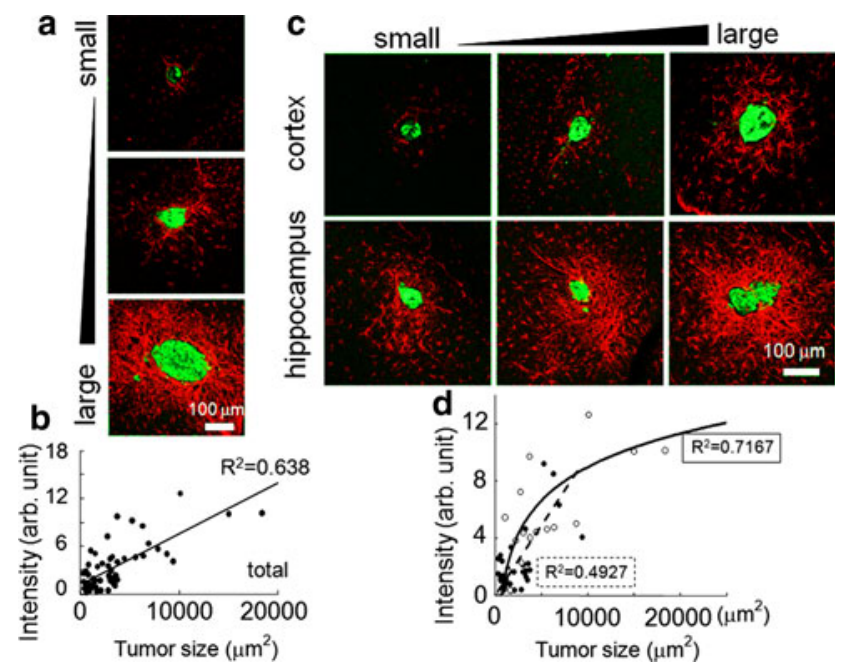

Fig. 1 Astrocyte accumulates around HARA-B cells in vivo. a Typical examples of immunostaining of astrogliosis (GFAP) around invaded tumor cells (human cytokeratin, CK). Accumulation of GFAP-positive astrocytes has relation to the size of the tumors. $\mathbf{b}$ Correlation between tumor size and astrogliosis. Accumulation of astrocytes was indicated as an intensity of GFAP fluorescence. $\mathbf{c}$ Typical examples of immunostaining indicating more accumulation of astrocytes in hippocampus than in cerebral cortex. d Correlation curve between tumor size and GFAP intensity in cortex (closed circle) and hippocampus (open circle). In hippocampus, astrogliosis around metastatic tumor foci increased logarithmically with correlation factor $\left(R^{2}\right)$ of 0.72

there are correlations between astrocytes and metastatic tumor cells in the microenvironment of brain metastasis.

Effects of astrocytes on the proliferation of HARA-B cells in vitro

In order to elucidate the relationship between astrocytes and HARA-B cells, interaction between 2 cell types was tested in vitro. Primary cultured mouse astrocytes were used and co-cultured with HARA-B cells. The proliferation of HARA-B cells was increased in co-culture with astrocytes in comparison to that in the control (in the absence of astrocytes). In addition, more astrocytes and longer incubation time yielded more proliferation of HARA-B cells (Fig. 2a). The relative increase of proliferation at a ratio of HARA-B cells to astrocytes of $1: 5$ and $1: 10$ were $285 \pm 9.5 \%(n=6)$ and $441 \pm 11.2 \%(n=6)$, respectively. Since the proliferation of cells in culture system depends on the cell number and physical contact, the effects of conditioned medium on the proliferation of HARA-B cells were examined. First, to avoid physical contact, HARA-B cells were cultured in insert-well with astrocytes in lower-well (ratio of HARA-B to astrocytes was $1: 10)$. After 48 of insert-culture, the medium was collected and added to HARA-B cells and incubated for 48 or $72 \mathrm{~h}$, and then the cell number was counted. Since the 


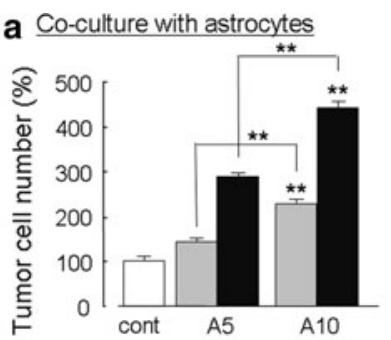

b Insert-culture medium treatment

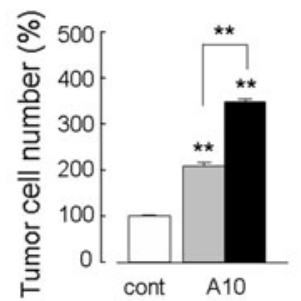

C

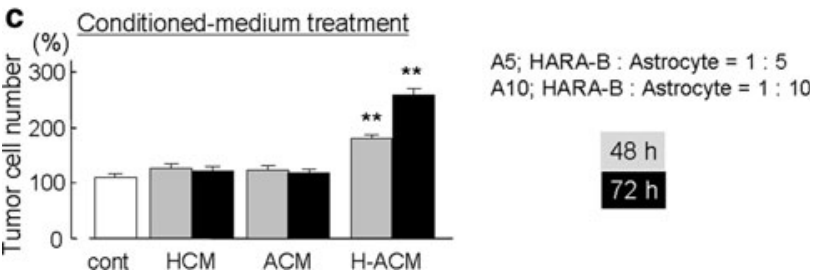

Fig. 2 Astrocyte stimulated the proliferation of tumor cells via soluble factors. a The normalized number of HARA-B cells increased according to the ratio of astrocytes to HARA-B cells and incubation time in co-culture treatment (HARA-B cells : astrocytes $=1: 5$, A5; HARA-B cells : astrocytes $=1: 10$, A10). b Culture medium from insert-culture of astrocytes with HARA-B cells (HARA-B cells : astrocytes $=1: 10$, A10) significantly increased the proliferation of tumor cells compared to the one without insert-culture medium (control). c H-ACM (HARA-B-stimulated astrocyte-conditioned medium), but not HCM (HARA-B-conditioned medium) nor ACM (astrocyte-conditioned medium) significantly increased the proliferation of tumor cells. The incubation time was $48 \mathrm{~h}$ (gray bars) and $72 \mathrm{~h}$ (black bars). Each value represents the mean \pm SEM $(\mathrm{n}=6)$. ** $P<0.01$

medium from insert-culture also increased the proliferation of HARA-B cells, it was suggested that some soluble factors were induced, presumably in astrocytes, without physical cell-cell contact between astrocytes and HARA-B cells (Fig. 2b). Second, it was investigated whether astrocyte-induced soluble factors are constitutive or inducible. Neither astrocyte-conditioned medium (ACM) nor HARAB-conditioned medium (HCM) but medium from HCMtreated astrocytes $(\mathrm{H}-\mathrm{ACM})$ significantly increased the proliferation of HARA-B cells after 48 or $72 \mathrm{~h}$ of treatment (Fig. 2c). These results suggest that astrocytes could be stimulated by some soluble factors released from tumor cells, and then produce some growth-promoting factors for tumor cells in turn.

Identification of soluble factors produced by astrocytes

To identify growth-promoting soluble factors produced by astrocytes, mRNA expression of several cytokines and/or growth factors were examined. Activated astrocytes have been shown to produce a wide variety of cytokines including interleukin-1 (IL-1), interleukin-3 (IL-3), interleukin-6 (IL-6), tumor necrosis factor- $\alpha$ (TNF- $\alpha$ ), transforming growth factor- $\beta$ (TGF- $\beta$ ), insulin-like growth factor-1 (IGF-1) and platelet-derived growth factor (PDGF)

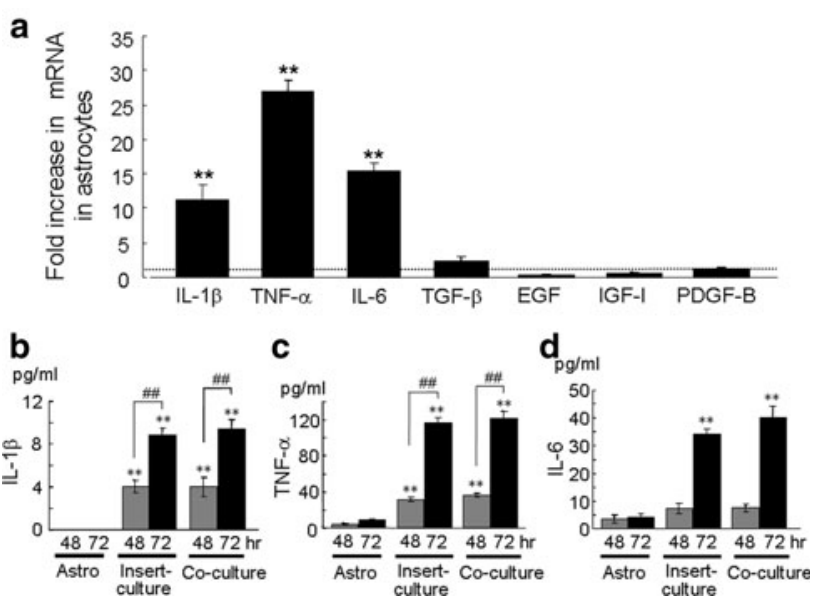

Fig. 3 Expression of mRNA and release of cytokines and growth factors from activated astrocytes. (a) Quantitative RT-PCR of IL- $1 \beta$, IL-6, TNF- $\alpha$, transforming growth factor- $\beta$ (TGF- $\beta$ ), insulin-like growth factor-1 (IGF-1), epidermal growth factor (EGF), and plateletderived growth factor-B (PDGF-B) in astrocytes insert-cultured with HARA-B cells. The expression level of each cytokine or growth factor mRNA was normalized to the level of each cytokine in astrocytes cultured alone. The relative values of each cytokine mRNA in insert-cultured astrocytes for $72 \mathrm{~h}$ are shown. Each value represents the mean $\pm \operatorname{SEM}(n=3)$. Release of IL-1 $\beta(\mathbf{b})$, TNF- $\alpha(\mathbf{c})$ and IL-6 (d) into the culture medium of single-culture of astrocytes (Astro), insert-culture or co-culture of astrocytes and HARA-B cells for 48 and $72 \mathrm{~h}$ were detected by ELISA. Each value represents the mean $\pm \operatorname{SEM}(n=6)$. ** $P<0.01,{ }^{\# \#} P<0.01$

[6-8]. To discriminate astrocytes-derived cytokines (mouse-origin) from HARA-B-derived cytokines (humanorigin), primers for mouse cytokines which do not crossreact to human cytokines were used (Table 1). The amplification of mRNA shows that marked increases in the expression of IL- $1 \beta$, TNF- $\alpha$ and IL- 6 were found in astrocytes after $72 \mathrm{~h}$ in the insert-culture with HARA-B cells. The relative expression levels of IL- $1 \beta$, TNF- $\alpha$ and IL-6 increased to $11.4 \pm 2.2,26.9 \pm 1.9$ and $15.4 \pm 1.1$ fold $(n=3$ each), respectively. On the other hand, expressions of EGF, TGF- $\beta$, IGF-I and PDGF-B did not show significant change even after $72 \mathrm{~h}$ of the insert-culture with HARA-B cells (Fig. 3a). The RT-PCR for human-IL- $1 \beta$, human-TNF- $\alpha$ and human-IL-6 in HARA-B cells with or without insert-culture with astrocytes was also performed but the fold increase in mRNA was not significant for either cytokine (data not shown). These results suggest that the origin of IL- $1 \beta$, TNF- $\alpha$ and mouse-IL- 6 were astrocytes but not HARA-B cells.

We also measured the protein levels of mouse-IL- $1 \beta$, mouse-TNF- $\alpha$ and mouse-IL- 6 in the conditioned medium obtained from single-cultured astrocytes (Astro), insertcultured astrocytes (insert-culture), and co-cultured astrocytes (co-culture) with HARA-B cells after $72 \mathrm{~h}$ incubation. Significant increase in the amounts of IL- $1 \beta$ and TNF- $\alpha$ was 
observed after 48 and $72 \mathrm{~h}$ of insert-culture and co-culture (Fig. 3b, c), while the increase in IL-6 release was only observed after $72 \mathrm{~h}$ of insert-culture and co-culture (Fig. 3d). The amounts of each cytokine after $72 \mathrm{~h}$ in astrocyte-culture, co-culture, and insert-culture were 0 (not detectable), $8.8 \pm 0.7$ and $9.4 \pm 0.8, \mathrm{pg} / \mathrm{ml}$ for IL- $1 \beta$, $8.3 \pm 1.3,116 \pm 5.5$ and $121 \pm 7.9 \mathrm{pg} / \mathrm{ml}$ for TNF- $\alpha$, and $4.2 \pm 1.3, \quad 34.2 \pm 1.9$ and $40 \pm 4.2 \mathrm{pg} / \mathrm{ml}$ for IL-6, respectively $(n=6)$.

Effects of recombinant IL- $1 \beta$, TNF- $\alpha$ and IL- 6 and their neutralizing antibodies on the proliferation of HARA-B cells

To confirm the effects of IL- $1 \beta$, TNF- $\alpha$ and IL-6, recombinant mouse (m) IL- $1 \beta$, mTNF- $\alpha$ and mIL- 6 were applied to HARA-B cells. The concentrations of IL- $1 \beta$, TNF- $\alpha$ and IL-6 used were employed according to the levels of these cytokines observed in the insert- or co-culture medium (Fig. 3b, c, d). Mouse-IL- $1 \beta$ in a range of $1-10 \mathrm{pg} / \mathrm{ml}$, but not high concentration $(50 \mathrm{pg} / \mathrm{ml})$, promoted the

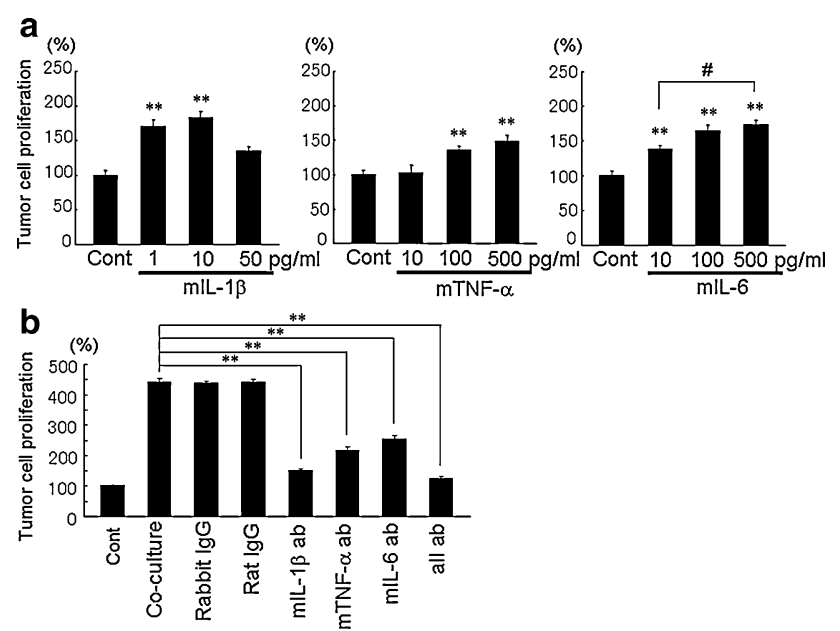

Fig. 4 Effects of recombinant cytokines on HARA-B cell proliferation and inhibitory effects of neutralizing antibodies. a Effects of recombinant mouse (m) IL- $1 \beta(1-50 \mathrm{pg} / \mathrm{ml})$, mTNF- $\alpha(10-500 \mathrm{pg} /$ $\mathrm{ml})$, and mIL-6 (10-500 pg/ml). Data were given as the percentage of tumor cell proliferation without cytokines (without recombinant cytokines; 100\%). HARA-B cells were cultured for $24 \mathrm{~h}$ in DMEM and then for $48 \mathrm{~h}$ in serum free DMEM with each cytokine. Each value represents the mean $\pm \operatorname{SEM}(n=6)$. b Effects of neutralizing antibodies. Anti-mIL-1 $\beta(1 \mu \mathrm{g} / \mathrm{ml})$, anti-mTNF- $\alpha(1 \mu \mathrm{g} / \mathrm{ml})$, antimIL-6 (10 ng/ml) neutralizing antibodies, all three antibodies (all ab) and corresponding control IgG were added to co-culture of HARA-B cells and astrocytes. Antibodies were added after $24 \mathrm{~h}$ of co-culture of HARA-B cells and astrocytes, and then maintained for $48 \mathrm{~h}$ with neutralizing antibodies or control IgG. Data were given as the percentage of control (single-culture of HARA-B cells; 100\%) under the same condition without adding antibodies. Each value represents the mean $\pm \operatorname{SEM}(\mathrm{n}=5)$. $* * P<0.01,{ }^{\#} P<0.05$ proliferation of HARA-B cells (Fig. 4a). Mouse-TNF- $\alpha$ and mIL-6 (10-500 pg/ml each) showed growth-promoting effect on HARA-B cells in a dose-dependent manner (Fig. 4a). These results show that IL-1 $\beta$, TNF- $\alpha$ and IL-6 released from mouse astrocytes could increase the proliferation of human-origin HARA-B cells.

In reverse, neutralizing antibodies against $\mathrm{mIL}-1 \beta$, mTNF- $\alpha$ and mIL- 6 inhibited the effects of co-culture. The titrations of each antibody used (mIL-1 $\beta$ and mTNF- $\alpha$ antibody: $0.2-2.0 \mu \mathrm{g} / \mathrm{ml}$, mIL-6 antibody: $2.0-20 \mathrm{ng} / \mathrm{ml}$ ) were determined according to the maximal neutralizing concentration (data not shown). The proliferation of HARA-B cells was promoted to $449 \pm 10.2 \%$ after co-culture with astrocytes for $72 \mathrm{~h}$ in comparison to that in the control (single-culture of HARA-B cells). The antibodies against mIL- $\beta(1 \mu \mathrm{g} / \mathrm{ml})$, mTNF- $\alpha(1 \mu \mathrm{g} / \mathrm{ml}), \mathrm{mIL}-$ $6(10 \mathrm{ng} / \mathrm{ml})$ and all three antibodies were added at $24 \mathrm{~h}$ after the co-culture of HARA-B cells with astrocytes, and the co-culture were maintained for further $48 \mathrm{~h}$ in the presence of these antibodies. The proliferation of HARA-B cells was significantly attenuated to $149 \pm 7.0$, $217 \pm 10.8,253 \pm 11$ and $126 \pm 5.9 \%$ in the presence of antibodies against IL- $1 \beta$, TNF- $\alpha$, IL-6 and all three antibodies, respectively ( $n=5$ each) (Fig. $4 \mathrm{~b}$ ).

Identification of tumor cell-derived factors which activate astrocytes

We then identified HARA-B-derived factors which activate astrocytes and promote expression of IL- $1 \beta$, TNF- $\alpha$, and IL-6. The factors in HARA-B cells culture medium was analyzed using the cytokine proteome profiler. The increased expression of cytokines in HARA-B conditioned medium compared to control (10\% FBS DMEM) were IL-1ra, IL-2, IL-8, MIF, and SERPINE1 (PAI-1) (Fig. 5a). Among them, IL-8, MIF, and PAI-1 which showed greater expression were tested whether they really activate mouse astrocytes and stimulate the production of IL- $1 \beta, \mathrm{TNF}-\alpha$, and IL-6. The expression of TNF- $\alpha$ mRNAs in astrocytes were significantly increased by recombinant human IL- 8 (hIL-8, 10-100 ng/ml) and hMIF (10-100 ng/ml) $(n=3$ each) (Fig. 5b). The TNF- $\alpha$ mRNA level was not detected with the application of hPAI-1 somehow (not shown). The expression of IL- $1 \beta$ mRNAs in astrocytes were also significantly increased by hIL-8 (100 ng/ml), hMIF $(10-100 \mathrm{ng} / \mathrm{ml})$, and hPAI-1 $(100-1000 \mathrm{ng} / \mathrm{ml}) \quad(n=3$ each) (Fig. 5c). The expression of IL-6 mRNAs in astrocytes were significantly increased by hMIF (10-100 $\mathrm{ng} / \mathrm{ml})$, and hPAI-1 (10-100 ng/ml) but not by hIL-8 ( $n=3$ each) (Fig. 5d). From these results, tumor-derived MIF would be the most potential candidate for stimulating astrocyte and IL-8 and PAI-1 may be less responsible. 
a

$10 \%$ FBS DMEM

HARA-B conditioned medium
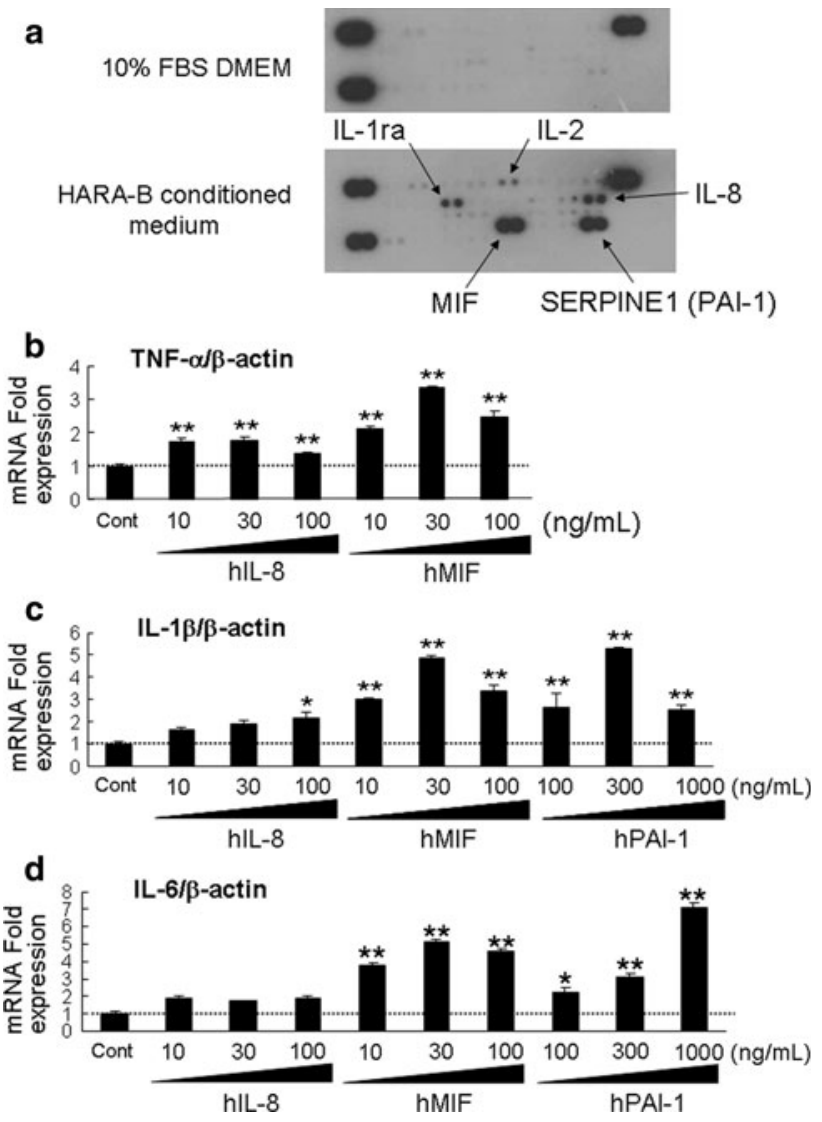

Fig. 5 HARA-B-derived factors which stimulate astrocytes and their effects on expression of mRNA of inflammatory cytokines in astrocytes. a Cytokine expression in HARA-B cells culture medium using the proteome profiler. The cytokine expression in medium $(10 \%$ FBS DMEM) as negative control (upper panel) and in HARA-B conditioned medium (lower panel), showing the expression of IL-1ra, IL-2, IL-8, MIF, and SERPINE1 (PAI-1). b-d Expression of mRNA of inflammatory cytokines (TNF- $\alpha$, IL- $1 \beta$, IL-6) in astrocytes treated with each recombinant cytokines (IL-8, MIF, PAI-1). Quantitative RT-PCR of TNF- $\alpha(\mathbf{b})$, IL-1 $\beta$ (c), and IL-6 (d) in astrocytes treated with each cytokine released from HARA-B cells IL-8, MIF, and PAI1. The expression level of each cytokine was normalized to the level of each cytokine in non-treated astrocytes. The relative values of each cytokine mRNA in astrocyte treated with each cytokine for $72 \mathrm{~h}$ are shown. Each value represents the mean \pm SEM $(n=3)$. Data of PAI-1-treatment was not shown in TNF- $\alpha$ mRNA

\section{Expression of cytokine receptors on HARA-B cells}

The expression of receptors for IL- $1 \beta$, TNF- $\alpha$ and IL- 6 on HARA-B cells were examined by the immunocytochemical staining. Receptors and receptor subunit for these cytokines were detected on cytokeratin-positive HARA-B cells by using antibodies against human-IL-1RtI, humanTNFRtI, human-IL-6R $\alpha$ and human-gp130. All of these receptors were detected in single-cultures of HARA-B cells (control) (Fig. 6a). To examine the time-dependent change in the expression level for each cytokine receptor and receptor subunit on HARA-B cells, the immunostaining was observed after 24,48 and $72 \mathrm{~h}$ of co-culture with astrocytes. The semi-quantitative analyses showed that the expression level for IL-1RtI and TNFRtI decreased with time after co-culture, while the expression level for IL-6R $\alpha$ and gp130 were up-regulated in co-culture with astrocytes (Fig. 6b). These results suggest that IL-6 receptors on HARA-B cells may be more functional when HARA-B cells were co-cultured with astrocytes and IL- 6 may be the most important cytokine in the promotion of HARA-B cell proliferation in the brain.

Effects of astrocytes on the growth of different lung tumor cell lines in vitro

To test if the mutual stimulation between astrocytes and lung cancer cells was general observation and not specific to HARA-B cells, three other cell lines derived from human squamous cell carcinoma (QG56, EBC-1) and nonsmall cell lung cancer (PC-9) were examined in vitro. Primary cultured astrocytes, which were prepared from C57BL/6 mice brain, were insert-cultured with other lung tumor cells in the ratio of 1:10 (lung tumor cells : astrocytes). The proliferation of each lung tumor cells increased to $210 \pm 27 \% \quad(\mathrm{QG} 56, \quad n=4), 480 \pm 43 \% \quad(\mathrm{EBC}-1$, $n=4)$, and $150 \pm 12 \%$ (PC9, $n=4)$ after $72 \mathrm{~h}$ of incubation with insert-culture medium (ICM), respectively (Fig. 7). These results show that astrocytes, activated by the soluble contact with lung cancer cells, promote not only the growth of HARA-B cells but also that of other lung cancer cells, suggesting that mutual activation of astrocytes and lung tumor cells are common phenomena.

Astrogliosis around human brain metastasis of lung tumor

Since activated astrocytes gathered around brain metastasis in model mice, we examined whether the same pathology was observed in human tissue from brain with lung cancer metastasis. We observed brain metastasis of lung tumor in human tissue sections by Hematoxylin-Eosin staining (Fig. 8a). GFAP-positive astrocytes, which means activated astrocytes, accumulated around metastatic foci (Fig. 8b).

\section{Discussion}

Certain cancers, i.e. breast cancer and lung cancer, are liable to metastasize in the brain. The incidence of the brain metastasis has been increasing in recent years [1]. In the metastatic process, the microenvironment of the metastatic sites plays an important role for tumor cells to invade and proliferate in the target tissues [2]. Such a 

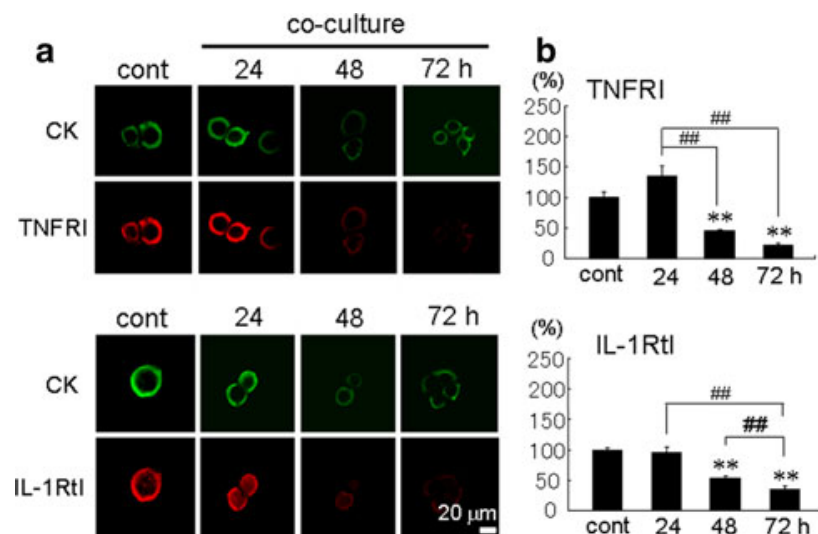

$48 \quad 72 \mathrm{~h}$
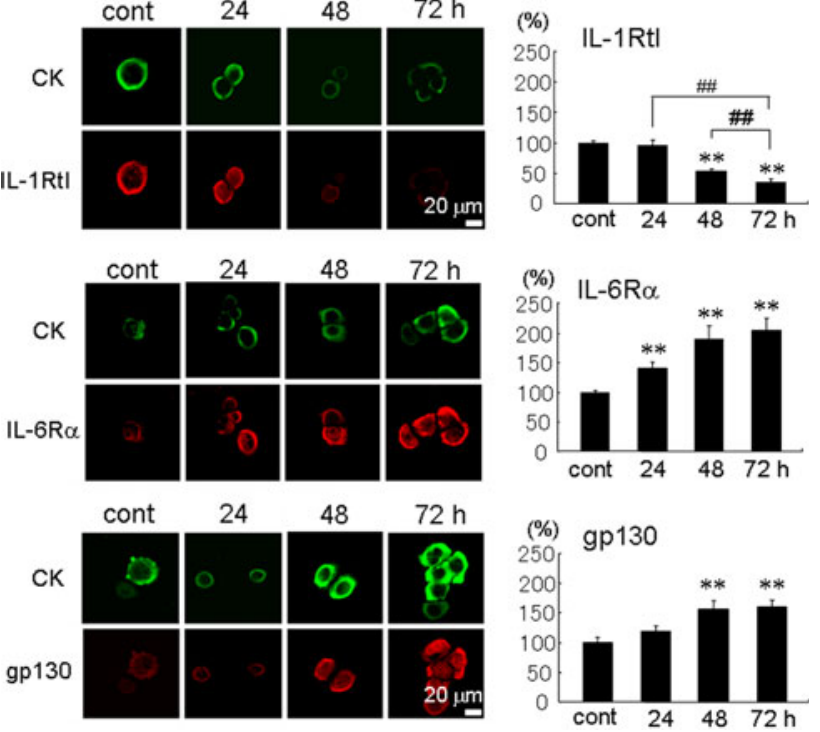

Fig. 6 Time-dependent expression of cytokine receptors on HARA$\mathrm{B}$ cells. a Immunostaining of cytokine receptor and receptor subunit (IL-6R $\alpha$, gp130, TNFRtI and IL-1RtI) on HARA-B cells with or without co-culture with astrocytes for 24,48 , and $72 \mathrm{~h}$. HARA-B cells were also immunostained with anti-cytokeratin (CK) antibody. b Quantification of fluorescent intensity for each receptor or receptor subunit per area of single cell. Data were given as the percentage of intensity in control HARA-B cells without co-culture (100\%). Each value represents the mean $\pm \operatorname{SEM}(n=8)$. ** $P<0.01,{ }^{\# \#} P<0.01$

microenvironment contains many resident cell types in addition to tumor cells as well as migratory hematopoietic cells.

Though activated astrocytes and soluble factors produced by glial cells in vivo seem to play an important role in the development of brain metastases [5], mechanisms of brain metastases induced by lung cancer cells remained unclear.

In the present study, histological examination revealed that activated astrocytes accumulated around the metastatic foci of human lung cancer-derived cell line, HARA-B cells, in the brain. Similar accumulation of astrocytes around brain metastases was also observed in human brain section from patients with lung cancer metastasis (Fig. 8), as well as in autopsy cases [14]. In our animal models, brain metastases were observed not two but three weeks after intracardiac inoculation of HARA-B cells, mostly in lateral cortex including hippocampus where more GFAPpositive astrocytes were observed even in control condition

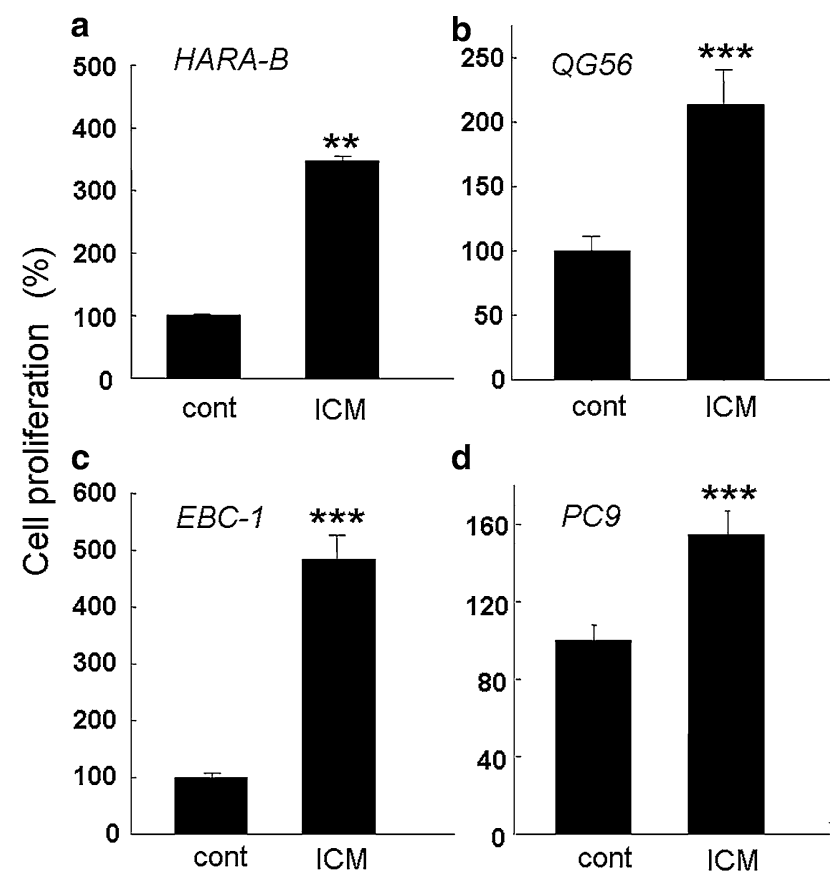

Fig. 7 Increased proliferation of different lung cancer cell lines by astrocytes in vitro. The proliferation of HARA-B cells (a), QG56 (b), EBC-1 (c), PC9 (d) were enhanced when they were incubated with insert-culture medium of astrocytes for $72 \mathrm{~h}$. Each value represents the mean \pm S.E.M $(n=4)$. *** $P<0.005$ (significance from control)

(data not shown). In later phase of metastases, 4-6 weeks after inoculation, more metastases were observed in whole brain, especially in cerebral cortex. These informations might be useful to understand the process of brain metastasis and its diagnosis.

From our in vitro studies, it was suggested that astrocytes, activated by tumor cells even in the absence of physical contact, promote the proliferation of lung cancer cells by releasing trophic factors. Using one of the lung cancer cell lines, HARA-B cells, IL- $1 \beta$, TNF- $\alpha$ and IL-6 were identified as astrocyte-oriented factors. It is known that activated astrocytes produce various inflammatory cytokines. IL-1, one of the inflammatory cytokines, has been shown to stimulate the growth of tumor cells in hepatic and/or lung metastases of melanoma tumor cells in vivo [15-17]. Sierra et al. [11] demonstrated that the growth of the breast cancer cell line, which was derived from a brain metastasis, was stimulated by the astrocytes through IL-6, TGF- $\beta$ and/or IGF-1 in vitro. In brain metastasis of melanoma cells, it was reported that astrocytes produce neurotrophin-regulated heparanase [18, 19]. Recently, it was also reported that epidermal growth factor receptor (EGFR) and membrane type-1 matrix metalloproteinase (MT1-MMP) may be playing an important role in brain metastasis from lung adenocarcinoma and breast cancer [20]. All these results suggest that tumor-promoting 
a

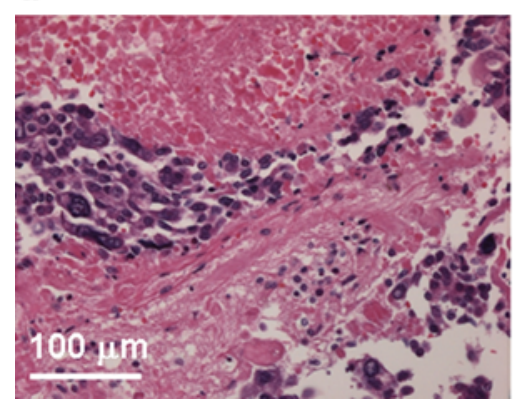

b

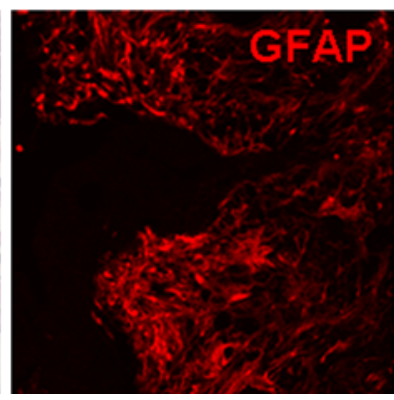

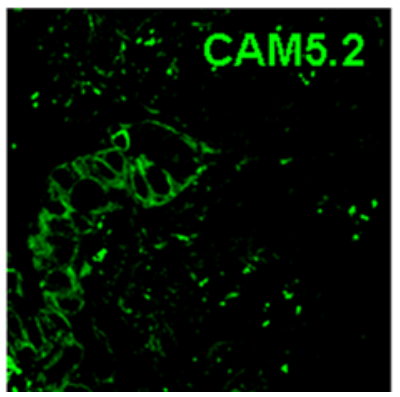

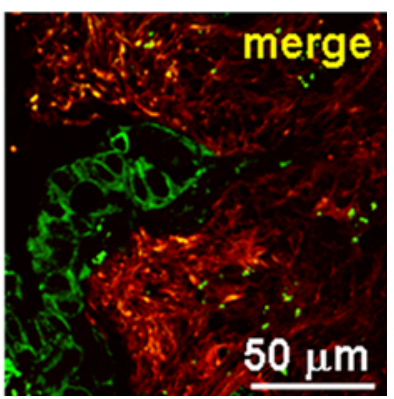

Fig. 8 Astrocytes accumulate around metastasized lung cancer cells in human brain. a Hematoxylin and eosin (H \& E)-staining of lung cancer cell metastasis (dark color) in the human brain section. b Immunostaining of astrocytes and tumor cells from human brain section. GFAP-positive astrocytes aggregated around cancer cells (CAM5.2), which looked similar to the brain metastasis of model mice

CD74, was recently discovered and was found that CD74 and MIF were co-expressed in tumors in close proximity, and that co-expression of the MIF-CD74 pair was associated with both higher levels of tumor-associated angiogenic CXC chemokines and greater vascularity [28]. Importantly, expression level of MIF, together with CD147 proteins, in non-SCLC were related to the metastasis. Survival rate was markedly lower in patients with high expression level of MIF or CD147 [29]. It was also shown that MIF overexpression by adenovirus in human lung adenocarcinoma cells induces a dramatic enhancement of cell migration [30].

Urokinase plasminogen activator (uPA) and its inhibitor PAI-1 stimulate angiogenesis in non-SCLC [31] and a crucial role of PAI-1 in lung cancer invasiveness and influence on prognosis were reported [32-34]. Increased PAI-1 expression and stabilization of PAI-1 mRNA in human lung epithelial and carcinoma cells were regulated by tumor suppressor protein p53 [35]. Taken together, IL-8, MIF, and PAI-1 in lung cancer cells are important not only for invasiveness and prognosis but also as stimulants for astrocytes after brain metastasis.

Stimulated astrocytes by the factors mentioned above release IL- $1 \beta$, TNF- $\alpha$ and IL-6. In our present study, expression of their receptors on HARA-B cells was confirmed immunocytochemically. Interestingly, the timedependent change in the expression of receptors for each cytokine seemed different in vitro. IL-6 receptor and its subunit, gp130, were up-regulated with time, while expression of receptors for IL- $1 \beta$ and TNF- $\alpha$ were downregulated. It was reported that leukocytes rapidly lose their surface receptors for TNF and IL-1 upon exposure to various stimuli in vitro and in fact lipopolisaccharide (LPS) induced down-regulation of monocyte and granulocyte receptors for TNF and IL-1 in humans in vivo [36]. In parallel, the release of IL-6 looked to be delayed compared to that of IL- $1 \beta$ and TNF- $\alpha$ (Fig. 3b, c, d). Taking account the biomarkers of non-SCLC [27]. The MIF receptor, 
of these evidences, IL- $1 \beta$ and TNF- $\alpha$ might play an important role at the beginning, then IL- 6 and its receptors would become more important functionally when brain metastases take place during long period. This might be the reason why the effects of neutralizing antibodies against IL- $1 \beta$ and TNF- $\alpha$ looked apparently robust when they were added during the first 24-72 h of co-culture. Considering the long-lasting effect of IL-6, blocking IL-6 may be useful not only for autoimmune and chronic inflammatory diseases [37] but also for brain metastasis. In vivo analyses on the effects of these cytokine blockages are now under investigation.

The role of activated microglia also needs to be investigated. It was reported that differential reactions of microglia to brain metastasis of lung cancer [38], showing an obvious increase in the number of microglia around metastatic lung cancer mass in the brain. However, only a few microglia expressed inducible nitric oxide synthase (iNOS) and TNF- $\alpha$ in the region where the tumor mass was situated. In vitro study, LPS-activated microglia showed both apoptotic effect and trophic effect, depending on the concentration of supernatant. Since the mechanism would be different between LPS- and metastasis-induced microglial activation, further investigation would be necessary.

In conclusion, the present results showed that the interaction between metastatic tumor cells and activated astrocytes are important in creating a favorable microenvironment for the tumor cells in the brain. They stimulate each other; first lung tumor cells stimulate astrocytes by releasing IL-8, MIF, and PAI-1, then activated astrocytes stimulate the proliferation of tumor cells by releasing cytokines such as TNF- $\alpha$, IL- $1 \beta$, and IL-6. These mutual relationships may be important to understand how lung cancer cells metastasize and develop in the brain.

Acknowledgments We thank Prof. D. A. Brown (University College London, UK) for reading the manuscript. This work was supported by Grants-in Aid for Scientific Research of Japan Society for Promotion of Science.

Conflict of interest All authors have no conflict of interest and no financial conflicts.

Open Access This article is distributed under the terms of the Creative Commons Attribution Noncommercial License which permits any noncommercial use, distribution, and reproduction in any medium, provided the original author(s) and source are credited.

\section{References}

1. Schouten LJ, Rutten J, Huveneers HA, Twijnstra A (2002) Incidence of brain metastases in a cohort of patients with carcinoma of the breast, colon, kidney, and lung and melanoma. Cancer 94:2698-2705
2. Fidler IJ, Yano S, Zhang RD et al (2002) The seed and soil hypothesis: vascularisation and brain metastases. Lancet Oncol 3:53-57

3. Aloisi F, Ria F, Adorini L (2000) Regulation of T-cell responses by CNS antigen-presenting cells: different roles for microglia and astrocytes. Immunol Today 21:141-147

4. Balkwill F, Mantovani A (2001) Inflammation and cancer: back to Virchow? Lancet 357:539-554

5. Fitzgerald DP, Palmieri D, Hua E et al (2008) Reactive glia are recruited by highly proliferative brain metastases of breast cancer and promote tumor cell colonization. Clin Exp Metastasis 25(7):799-810

6. Miller RH, Ffrench-Constant C, Raff MC (1989) The macroglial cells of the rat optic nerve. Annu Rev Neurosci 12:517-534

7. Aloisi F, Care A, Borsellino G et al (1992) Production of hemolymphopoietic cytokines (IL-6, IL-8, colony-stimulating factors) by normal human astrocytes in response to IL-1 beta and tumor necrosis factor-alpha. J Immunol 149:2358-2366

8. Hertz L, McFarlin DE, Waksman BH (1990) Astrocytes: auxiliary cells for immune responses in the central nervous system? Immunol Today 11:265-268

9. Lee SC, Liu W, Dickson DW et al (1993) Cytokine production by human fetal microglia and astrocytes. Differential induction by lipopolysaccharide and IL-1 beta. J Immunol 150:2659-2667

10. Wang FW, Jia DY, Du ZH et al (2009) Roles of activated astrocytes in bone marrow stromal cell proliferation and differentiation. Neuroscience 160(2):319-329

11. Sierra A, Price JE, Garcia-Ramirez M et al (1997) Astrocytederived cytokines contribute to the metastatic brain specificity of breast cancer cells. Lab Invest 77:357-368

12. Iguchi H, Tanaka S, Ozawa Y et al (1996) An experimental model of bone metastasis by human lung cancer cells: the role of parathyroid hormone-related protein in bone metastasis. Cancer Res 56:4040-4043

13. Lyons S, Kettenmann K (1998) Oligodendrocytes and microglia are selectively vulnerable to combined hypoxia and hypoglycemia injury in vitro. J Cereb Blood Flow Metab 18:521-530

14. Zhang M, Olsson Y (1995) Reactions of astrocytes and microglial cells around hematogenous metastases of the human brain. Expression of endothelin-like immunoreactivity in reactive astrocytes and activation of microglial cells. J Neurol Sci $134: 26-32$

15. Giavazzi R, Garofalo A, Bani MR et al (1990) Interleukin 1-induced augmentation of experimental metastases from a human melanoma in nude mice. Cancer Res 50:4771-4775

16. Vidal-Vanaclocha F, Amezaga C, Asumendi A et al (1994) Interleukin-1 receptor blockade reduces the number and size of murine B16 melanoma hepatic metastases. Cancer Res 54: 2667-2672

17. Vidal-Vanaclocha F, Alvarez A, Asumendi A (1996) Interleukin 1 (IL-1)-dependent melanoma hepatic metastasis in vivo; increased endothelial adherence by IL-1-induced mannose receptors and growth factor production in vitro. J Natl Cancer Inst 88:198-205

18. Marchetti D, Denkins Y, Reiland J et al (2003) Brain-metastatic melanoma: a neurotrophic perspective. Pathol Oncol Res 9(3):147-158

19. Denkins Y, Reiland J, Roy M et al (2004) Brain metastases in melanoma: roles of neurotrophins. Neuro Oncol 6(2):154-165

20. Yoshida S, Takahashi H (2009) Expression of extracellular matrix molecules in brain metastasis. J Surg Oncol 100(1):65-68

21. Iguchi H, Onuma E, Sato K et al (2001) Involvement of parathyroid hormone-related protein in experimental cachexia induced by a human lung cancer-derived cell line established from a bone metastasis specimen. Int J Cancer 94(1):24-27

22. Funk JL, Trout CR, Wei H et al (2001) Parathyroid hormonerelated protein $(\mathrm{PTHrP})$ induction in reactive astrocytes following 
brain injury: a possible mediator of CNS inflammation. Brain Res 915(2):195-209

23. Bauer M, Gräbsch C, Gminski R et al (2010) Cement-related particles interact with proinflammatory IL- 8 chemokine from human primary oropharyngeal mucosa cells and human epithelial lung cancer cell line A549. Environ Toxicol. doi:10.1002/tox.20643

24. Yang S, Su J, Cao J et al (2009) Establishment of a novel Chinese human lung adenocarcinoma cell line CPA-Yang1 which produces highly bone metastases in immunodeficient mice. Zhongguo Fei Ai Za Zhi 12(7):753-759

25. Liu Z, Xu S, Xiao N et al (2010) Overexpression of IL-8 and MMP-9 confer high malignant phenotype in patients with nonsmall cell lung cancer. Zhongguo Fei Ai Za Zhi 13(8):795-802

26. Crohns M, Saarelainen S, Laine $S$ et al (2010) Cytokines in bronchoalveolar lavage fluid and serum of lung cancer patients during radiotherapy-association of interleukin-8 and VEGF with survival. Cytokine 50(1):30-36

27. Khan N, Cromer CJ, Campa M, Patz EF Jr (2004) Clinical utility of serum amyloid $\mathrm{A}$ and macrophage migration inhibitory factor as serum biomarkers for the detection of nonsmall cell lung carcinoma. Cancer 101(2):379-384

28. McClelland M, Zhao L, Carskadon S, Arenberg D (2009) Expression of $\mathrm{CD} 74$, the receptor for macrophage migration inhibitory factor, in non-small cell lung cancer. Am J Pathol 174(2):638-646

29. Liu Q, Yang H, Zhang SF (2010) Expression and significance of MIF and CD147 in non-small cell lung cancer. Sichuan Da Xue Xue Bao Yi Xue Ban 41(1):85-90

30. Rendon BE, Roger T, Teneng I et al (2007) Regulation of human lung adenocarcinoma cell migration and invasion by macrophage migration inhibitory factor. J Biol Chem 282(41):29910-29918
31. Offersen BV, Pfeiffer P, Andreasen P, Overgaard J (2007) Urokinase plasminogen activator and plasminogen activator inhibitor type-1 in nonsmall-cell lung cancer: relation to prognosis and angiogenesis. Lung Cancer 56(1):43-50

32. Ramer R, Rohde A, Merkord J et al (2010) Decrease of plasminogen activator inhibitor-1 may contribute to the anti-invasive action of cannabidiol on human lung cancer cells. Pharm Res 27(10):2162-2174

33. Chorostowska-Wynimko J, Kedzior M, Struniawski R et al (2010) Cell phenotype determines PAI-1 antiproliferative effect-suppressed proliferation of the lung cancer but not prostate cancer cells. Pneumonol Alergol Pol 78(4):279-283

34. Di Bernardo MC, Matakidou A, Eisen T, Houlston RS (2009) GELCAPS Consortium. Plasminogen activator inhibitor variants PAI-1 A15T and PAI-2 S413C influence lung cancer prognosis. Lung Cancer 65(2):237-241

35. Shetty S, Shetty P, Idell S et al (2008) Regulation of plasminogen activator inhibitor-1 expression by tumor suppressor protein $\mathrm{p} 53$. J Biol Chem 283(28):19570-19580

36. van der Poll T, Coyle SM, Kumar A et al (1997) Down-regulation of surface receptors for TNF and IL- 1 on circulating monocytes and granulocytes during human endotoxemia: effect of neutralization of endotoxin-induced TNF activity by infusion of a recombinant dimeric TNF receptor. J Immunol 158(3):14901497

37. Mihara M, Ohsugi Y, Kishimoto T (2009) Evidence for the role of Th17 cell inhibition in the prevention of autoimmune diseases by anti-interluekin- 6 receptor antibody. Biofactors 35(1):47-51

38. He BP, Wang JJ, Zhang X et al (2006) Differential reactions of microglia to brain metastasis of lung cancer. Mol Med 12(7-8): $161-170$ 